\title{
Dissolved Organic Matter Quality and Biofilm Composition Affect Microbial Organic Matter Uptake in Stream Flumes
}

\author{
Gabriele Weigelhofer ${ }^{1,2, *} \mathbb{C}$, Tania Sosa Jirón ${ }^{1}{ }^{\mathbb{C}}$, Tz-Ching Yeh ${ }^{1}$, Gertraud Steniczka ${ }^{2}$ and \\ Matthias Pucher 1,2 (D) \\ 1 Institute of Hydrobiology and Aquatic Ecosystem Management, \\ University of Natural Resources and Life Sciences, 1180 Vienna, Austria; tsosajiron@gmail.com (T.S.J.); \\ zcyeh1105@gmail.com (T.-C.Y.); matthias.pucher@boku.ac.at (M.P.) \\ 2 Wasser Cluster Lunz-Biological Station GmbH, 3293 Lunz am See, Austria; gertraud.steniczka@wcl.ac.at \\ * Correspondence: gabriele.weigelhofer@wcl.ac.at; Tel.: +43-676-441-4590
}

Received: 9 September 2020; Accepted: 17 November 2020; Published: 19 November 2020

\begin{abstract}
Agriculture delivers significant amounts of dissolved organic matter (DOM) to streams, thereby changing the composition and biodegradability of the aquatic DOM. This study focuses on the interactive effects of DOM quality and biofilm composition on the degradation of DOM in a laboratory flume experiment. Half of the flumes were exposed to light to stimulate algal growth, the other half was shaded. Leachates of deciduous leaves, maize leaves, and cow dung were added to the flumes in a single pulse and changes of DOC (dissolved organic carbon) and nutrient concentrations, DOM composition (absorbance and fluorescence data), chlorophyll-a concentrations, bacterial abundances, and enzymatic activities were recorded over a week. DOM was taken up with

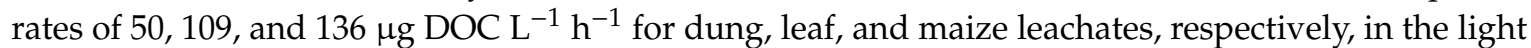
flumes and 37, 80, and $170 \mu \mathrm{g}$ DOC L ${ }^{-1} \mathrm{~h}^{-1}$ in the dark flumes. DOC uptake correlated strongly with initial SRP (soluble reactive phosphorus) and DOC concentrations, but barely with DOM components and indices. Algae mostly stimulated the microbial DOC uptake, but the effects differed among differently aged biofilms. We developed a conceptual model of intrinsic (DOM quality) and external (environmental) controlling factors on DOM degradation, with the microbial community acting as biotic filter.
\end{abstract}

Keywords: dissolved organic carbon; uptake; fluorescence; absorbance; phosphorus; biofilm; extra-cellular enzyme activity

\section{Introduction}

Worldwide, almost $40 \%$ of terrestrial surfaces have been converted to agricultural land by now and this trend is expected to increase in the future [1]. Agriculture delivers significant amounts of dissolved organic matter (DOM) to stream ecosystems, thereby changing also the composition and biodegradability of the aquatic DOM [2-4]. Natural streams are generally dominated by terrestrial, humic-like DOM originating from riparian vegetation [5]. Agriculture may shift this composition towards the dominance of protein-like labile components through the leaching of fertilized soils and plant residues and the rapid transport of this leached DOM to stream ecosystems via overland flow, preferential flow paths, or drainage waters [4-7]. Furthermore, the increased nutrient supply and the frequently enhanced light availability may stimulate the benthic primary production in agricultural streams, resulting in an increased autochthonous DOM production $[3,8]$.

Studies have shown that the composition of DOM is a key factor for the microbial DOM consumption and degradation in stream ecosystems and an important driver for benthic microbial 
activities, such as assimilation, growth, and respiration [9-13]. While monomers can be taken up directly through the cell membrane and thus show high uptake rates, polymeric and phenolic compounds need several steps of enzymatic reactions before the components are available for microbial anabolic or catabolic pathways [14-16]. Apart from molecular size, the age and degradation state of DOM may determine its bioreactivity [11,17]. Material leached from fresh litter, macrophytes, and periphyton, for example, has shown to yield higher proportions of low-molecular and protein-like compounds and is more metabolically active than compounds leached from soils and aged litter [18]. Ref. [11] found differences in metabolic pathways depending on the DOM composition, where fresh humic-like leachates from forest streams stimulated carbon assimilation and acid degradation, while DOM with a high protein-like character enhanced microbial respiration and carbohydrate decomposition [11].

In contrast to this intrinsic recalcitrance, some authors suggest that biodegradability is an ecosystem feature rather than a molecular property, as physicochemical and biological influences from the environment may enhance or reduce the probability and rate of decomposition $[19,20]$. Several studies have shown the importance of stoichiometric control of DOC uptake through limiting nutrients [2,21-24]. Enhanced phosphorus $(\mathrm{P})$ and nitrogen $(\mathrm{N})$ concentrations in the water column may shift the bioavailability of various carbon sources to a higher level. For example, ref. [25] observed a positive correlation between the bioavailability of DOM and the percentage of protein-like components, but the effects were overlaid by the nitrate availability as a key control. Besides, the DOM source itself can contain high amounts of inorganic and organic $\mathrm{N}$ and $\mathrm{P}[26,27]$.

Both autotrophic and heterotrophic microorganisms require inorganic $\mathrm{N}$ and $\mathrm{P}$ for their metabolism and growth, but only heterotrophs need organic carbon as energy and food source [3]. Thus, based on stoichiometric theory, increased algal abundances in biofilms should decrease heterotrophic DOC uptake due to competition for nutrients. Studies from both pelagic and benthic systems have shown that DOC additions may stimulate aquatic heterotrophs, but suppress autotrophs [3,28-30]. However, less is known about the stoichiometric effects of autotrophic nutrient uptake on the bacterial DOM degradation. Studies in stream ecosystems indicate that mutualistic interactions rather than nutrient competition exist between bacteria and algae in benthic biofilms, where algae profit from nutrient regeneration and $\mathrm{CO}_{2}$ supply by bacteria and bacteria profit from the enhanced generation of extracellular polymeric matrix by algae [31-33]. Indeed, autotrophic biofilms have shown higher average DOC uptake rates than heterotrophic biofilms in flume experiments [34]. Algae may influence bacterial abundances and activities positively by providing additional substrate for colonization and changing the biogeochemistry of the biofilm regarding $\mathrm{pH}$ or oxygen availability [35-37]. Besides, the polysaccharide matrix may enhance DOM adsorption [34]. On the other hand, dense internal carbon coupling under nutrient-limiting conditions may decrease the uptake of externally supplied DOC sources in the water column $[32,38,39]$.

As algae are key players in biofilm processes in agricultural streams, it is of imperative importance to study their role in bacterial DOM degradation in order to enhance our understanding of the underlying mechanisms of DOM uptake and transformation in such stream systems [32,34]. The current study focuses on the effects of DOM composition of different natural and anthropogenic sources (leaves, maize, and cow dung) on the microbial DOM uptake under different light conditions. Specifically, we wanted to know how DOM properties and/or community composition influenced the consumption and degradation of the selected DOM sources and whether algae could stimulate the microbial DOM uptake. We hypothesized that higher P contents (in P-limited systems) and more protein-like compounds will increase the degradation of the added DOM. Furthermore, we expected algae to stimulate the heterotrophic DOM uptake, despite competing for the available phosphorus. Our DOM addition study was performed in experimental flumes under controlled laboratory conditions with leachates from the original sources to exclude potential pre-processing within the soil and stream ecosystem [40].

\section{Materials and Methods}

For easier distinction, biofilms on glass slides are called epilithic biofilms, while biofilms on sand are termed epipsammic biofilms hereinafter. 


\subsection{Experimental Design}

We used flumes made of acrylic glass (55 cm length, $10.5 \mathrm{~cm}$ depth, $9 \mathrm{~cm}$ width), which were filled with $800 \mathrm{~g}$ of pre-cleaned $0.7-1.2 \mathrm{~mm}$ quartz sand up to a depth of $1 \mathrm{~cm}$. Rectangular glass slides $\left(19.76 \mathrm{~cm}^{2}\right)$ were placed loosely on top of the sand to provide stable substrates for algal growth. Each flume was operated in recirculating mode by an aquarium pump, which was submerged in a separate $5 \mathrm{~L}$ reservoir to facilitate individual DOM additions and water sampling. Porous distributors at both the inlet and the outlet of each flume ensured an even distribution of the flow through the flume (flow velocity approximately $5 \mathrm{~cm} \mathrm{~s}^{-1}$ ). Half of the flumes were exposed to a 14/10 h dark/light cycle using two daylight neon tubes (Philips Master Tl-D 58W/865 Fluorescent Tube, Daylight color, 5200 lumens), which resulted in $100 \mu \mathrm{mol} \mathrm{m} \mathrm{m}^{-2} \mathrm{~s}^{-1}$ photosynthetic-active radiation ("light flumes"). The other half was covered with fine, black nylon mesh to reduce light availability ("dark flumes"). All experiments were conducted at $20^{\circ} \mathrm{C}$ in a climate chamber. We used nutrient-enriched groundwater supplied from a well during the colonization phase, which was exchanged twice a week. Mean background concentrations in the source water were $1.2 \mathrm{mg} \mathrm{L}^{-1} \mathrm{NO}_{3}-\mathrm{N}$ and $1.2 \mathrm{mg} \mathrm{L}^{-1}$ dissolved organic carbon (DOC), while soluble reactive phosphorus (SRP) and $\mathrm{NH}_{4}-\mathrm{N}$ were increased from $<0.4 \mu \mathrm{g} \mathrm{L}{ }^{-1}$ background concentrations to $20 \mu \mathrm{g} \mathrm{L}{ }^{-1}$ by additions of $\mathrm{NH}_{4} \mathrm{Cl}$ and $\mathrm{Na}_{2} \mathrm{HPO}_{4}$-solutions. To facilitate biofilm growth, all flumes were inoculated with $10 \mathrm{~g}$ of fine sediments and $5 \mathrm{~mL}$ homogenized suspension of periphyton collected from a nearby stream.

For the preparation of the leachates, cow dung, mixed deciduous leaves, and maize leaves were sampled one month before the experiments, air-dried, and stored in a cool room in the dark, respectively. Immediately before the addition, the samples were homogenized and leached in nutrient-poor groundwater in the dark for $24 \mathrm{~h}(1 \mathrm{~g}$ solid material per $40 \mathrm{~mL})$. The leachates were filtered through Whatman GF/F filters $(0.75 \mu \mathrm{m})$ and analyzed for initial DOC and nutrient concentrations. Based on these data, the amount of leachate needed for each flume was calculated to achieve equal end concentrations of approximately $8 \mathrm{mg} \mathrm{DOC} \mathrm{L}^{-1}$ in all treatments. All DOM leachates were added in a single pulse after the water exchange. In the control flumes, only the water was exchanged, but no DOM, SRP, or $\mathrm{NH}_{4}-\mathrm{N}$ was added. We used three replicates per DOM treatment and two replicates for the control for each light level, respectively (in total, 22 flumes). Water samples were taken for DOC, nutrient concentrations, and DOM spectroscopic properties before the addition (day 0 ) and 4 , 24, 48, 96, and $168 \mathrm{~h}$ (i.e., 1/6, 1, 2, 4, and 7 days) after the addition. On days 0 and 7, we also took two glass slides and two sand samples from each flume to analyze organic matter and chlorophyll-a concentrations, bacterial abundances, and the activity of extra-cellular enzymes (EEA) in the biofilms. To determine the proportion of photodegradation, we exposed the DOM leachates to $24 \mathrm{~h}$ light at the same concentration as in the flumes and determined the DOC decrease.

In order to increase the number of replicates, the whole experiment was repeated in a second run under exactly the same conditions one month later. For the second run, the remaining biofilms of the first run were used as inoculum for the colonization.

\subsection{Analyses}

Water samples were filtered with pre-combusted Whatman GF/F filters $(0.75 \mu \mathrm{m})$ immediately after sampling and stored in pre-combusted glass vials at $4{ }^{\circ} \mathrm{C}$ in the dark. DOC concentrations were determined with a Sievers $* 000$ portable TOC-Analyzer (GE Analytical Instruments, Boulder, USA), and nutrient concentrations ( $\mathrm{SRP}, \mathrm{NH}_{4}-\mathrm{N}, \mathrm{NO}_{3}-\mathrm{N}$, and $\left.\mathrm{NO}_{2}-\mathrm{N}\right)$ were analyzed via a continuous flow analyzer (CFA, Systema Analytical Technology) within $24 \mathrm{~h}$ after sampling. Dissolved organic phosphorus (DOP) and dissolved organic nitrogen (DON) were determined after persulfate digestion in an autoclave and subtraction of SRP and $\mathrm{NO}_{3}-\mathrm{N}$, respectively [41].

The DOM composition was determined via optical characteristics immediately after sampling using absorbance and fluorescence analyses [42,43]. Absorbance scans were performed between 200 and $700 \mathrm{~nm}$ in $0.5 \mathrm{~nm}$ intervals with a UV-VIS spectrometer (UV1700 Pharma Spec, Shimadzu Corporation, Kyoto, Japan; $5 \mathrm{~cm}$ quartz cuvette). Fluorescence data were obtained using a fluorescence 
spectrophotometer with a xenon lamp (Hitachi F-7000, Hitachi High-Technology Corporation, Tokio, Japan). Fluorescence intensity was measured at excitation (ex) wavelengths from 200 to $450 \mathrm{~nm}$ and emission (em) wavelengths from 250 to $600 \mathrm{~nm}$ in $5 \mathrm{~nm}$ intervals in a $1 \mathrm{~cm}$ quartz cuvette. Measurements were blank-corrected against ultra-pure water, corrected against inner-filter effects [44] and normalized to Raman units.

Particulate organic matter (POM) and bacterial cell abundances were measured in both epilithic and epipsammic biofilms on days 0 and 7 (duplicates per flume). POM was determined via the ash free dry mass after combustion at $450{ }^{\circ} \mathrm{C}$ for $4 \mathrm{~h}$. For bacterial abundances in epipsammic biofilms, $1.3 \mathrm{~g}$ sand (fresh weight) were suspended in $3 \mathrm{~mL} \mathrm{GF} / \mathrm{F}$ filtered autoclaved stream water and fixed with $0.75 \mathrm{~mL} \mathrm{37 \%}$ formaldehyde. Epilithic biofilm samples were scraped off the glass slides, suspended in $50 \mathrm{~mL}$ Milli-Q water, and sonicated for $3 \mathrm{~min}$ (Elmasonic S $70 \mathrm{H}$ ). Subsamples of $5 \mathrm{~mL}$ were filtered through $5 \mu \mathrm{m}$ membrane filters and fixed in the same way as the sand samples. All fixed samples were kept in the fridge at $4{ }^{\circ} \mathrm{C}$ until further analysis. Staining followed the procedure provided by [45]. In short, bacteria were extracted with Tween 80 (10\%), sodium pyrophosphate solution (10 mM), and sterile filtered water (Acrodisc $0.22 \mathrm{~m}$ ). After several steps of sonication, manual shaking and ice baths, the suspension was filtered (MFTM-Milipore Membrane Filters, 5.0 m SMWP, Nitrocellulose Membrane, Merck KGaA, Darmstadt, Germany) and diluted. Bacteria were stained with Sybr Green II and counted with a flow cytometer (CytoFLEX, Beckman Coulter GmbH, Krefeld, Germany). Abundances were calculated on the base of sediment dry weight and surface area.

For the determination of chlorophyll-a concentrations and pigment compositions, the remaining periphyton suspensions were filtered onto Whatman GF-C filters $(1.2 \mu \mathrm{m})$. The filters were placed in $90 \%$ cold acetone, sonicated (ultrasonic probe), and extracted at $4{ }^{\circ} \mathrm{C}$ in the dark over $24 \mathrm{~h}$. After centrifugation (2500 rpm, $20 \mathrm{~min}$ ), the chlorophyll-a contents were determined with a Hitachi Fluorescence Spectrophotometer F-7000 [41]. In addition, $1 \mathrm{~mL}$ of each extract was analyzed for pigment composition via HPLC (Hitachi Elite LaChrom, Hitachi High Technologies America, San Jose, CA, USA). Pigments were transformed to the three main algal groups (diatoms, chlorophyta, and cyanobacteria) by simultaneous linear equations according to [46], using the pigment ratio matrix of [47]. Samples of epipsammic biofilms did not yield chlorophyll-a concentrations above the detection limit in any of the flumes (3 g sand in $10 \mathrm{~mL}$ 90\% acetone).

We performed enzyme assays with suspensions of epipsammic and epilithic biofilms in 96-well microplates as described in [48]. In short, biofilms in $3 \mathrm{~g}$ sand or on one glass slide were suspended in $5 \mathrm{~mL}$ filtered, autoclaved stream water, respectively (duplicates per flume). Suspensions were pipetted into the wells (two analytical replicates each) and incubated under saturated conditions in 4-Methylumbelliferyl $\beta$-D-glucopyranoside (MUF-Gluc), 4 Methylumbelliferyl phosphate (MUF-Phos), and L-Leucine 7-amino-4-methylcoumarinhydrochloride (AMC-Leu), resulting in end concentrations of $400 \mu \mathrm{M}$ each. The fluorescence was determined at 365/450 nm excitation/emission for MUF and 380/440 $\mathrm{nm}$ for AMC substrates at the beginning and after $1 \mathrm{~h}$ of incubation using a fluorescence microplate reader (Varioskan Flash, Thermo Fisher Scientific, Waltham, MA, USA). We used MUF and AMC standard rows based on homogenates of biofilm suspensions to account for quenching and background fluorescence. Extra-cellular enzyme activities (EEA) were calculated as concentration differences between the start and end of the incubation, corrected for sample size ( $g$ dry weight of sand or area of periphyton) and incubation time.

\subsection{Calculations}

DOC uptake rates were calculated as the relative decrease in DOC over time in each treatment flume corrected for the average DOC change over time in the control flumes to account for DOC uptake or production by biofilms without leachate additions. Most uptake curves followed a logarithmic curve with $\mathrm{r}^{2}$ values ranging between 0.9 and 0.99 . The only exceptions were the dark treatment for dung in run 1 (linear curve, $\mathrm{r}^{2}=0.98$ ) and the dark treatment for maize in run 2 (exponential curve, $\left.\mathrm{r}^{2}=0.97\right)$. We calculated the time needed for $50 \%$ DOC removal from the individual DOC uptake 
curves (T50). Due to the truncation of most uptake curves after 2-4 days, we calculated initial DOC uptake rates $(\mathrm{U})$ via a linear regression over the first $20 \mathrm{~h}$. These parameters allowed us to compare the uptake among the different flumes despite applying different uptake models.

The analysis of fluorescence and absorbance spectra of DOM was done in R version 3.6 (R Core Team 2020) and the packages eemR (https://cran.r-project.org/package=eemR; accessed on 26 June 2019) and staRdom [49]. Pre-processing of the fluorescence data included spectral correction, blank correction, inner-filter effect correction, Raman normalization, scatter removal, interpolation, and outlier identification by visual checks. Via PARAFAC (parallel factor) analysis, we identified four DOM components [50], two of which were interpreted as humic-like components of terrestrial origin (C1 and C3) and two as protein-like components from autochthonous sources (tryptophan-like C2 and tyrosine-like C4) (Table 1). Further outliers were identified by calculating the leverage [51], and the model was validated via a split-half analysis. The PARAFAC components were expressed as relative fluorescence intensities contributing to the total fluorescence of the sample.

Table 1. Fluorescence characteristics and description of the four PARAFAC components identified by the PARAFAC model. Descriptions and references were taken from comparisons with the 'openfluor' database [52]. ex = excitation, em = emission.

\begin{tabular}{cccc}
\hline Component & Ex/Em Wavelengths & Description & References \\
\hline C1 & ex $<230(320)$, em 420 & $\begin{array}{c}\text { humic-like, terrestrial, common in freshwaters, } \\
\text { exported from agricultural catchments } \\
\text { (C peak) }\end{array}$ & {$[4,53,54]$} \\
C2 & ex 285 (<230), em 350 & $\begin{array}{c}\text { tryptophan-like, microbial delivered } \\
\text { autochthonous; correlated to terrestrial } \\
\text { fluorophores }\end{array}$ & {$[4,53]$} \\
\hline C3 & ex 240/370/295, em 472 & $\begin{array}{c}\text { humic-like, terrestrial delivered, mixture of A } \\
\text { and C peaks; high molecular weight }\end{array}$ & {$[54,55]$} \\
\hline C4 & ex 275 $(<230)$, em 308 & $\begin{array}{c}\text { tyrosine-like; autochthonous sources; produced } \\
\text { and removed by the same processes as } \\
\text { tryptophan; correlated to terrestrial fluorophores }\end{array}$ & {$[4,53]$} \\
\hline
\end{tabular}

We used the peak picking method provided by the eemR package for the calculation of the following fluorescence indices: biological index (BIX), 'Coble-peaks' $b, t, a, m$, and c, fluorescence index (FI), and humification index (HIX) [56]. The individual peaks b, t, a, m, and c were corrected against the DOC concentrations of the respective samples to enable concentration-independent comparisons across treatments. The following absorbance indices were calculated: $\mathrm{SUVA}_{254}$ (specific UV absorbance at $254 \mathrm{~nm}$ normalized for DOC concentration), E2:E3 ratio (ratio of absorbance at $250 \mathrm{~nm}$ to that at $365 \mathrm{~nm}$ ), and the slope ratio (spectral slope S275-295 divided by spectral slope S350-400) $[57,58]$.

\subsection{Statistics}

We checked all data for normal distribution and homogeneity of variance with Kolmogorov-Smirnov, Shapiro-Wilks, and Levene tests. Variables were log-transformed to meet the assumption of normality and variance homogeneity whenever necessary. We used an analysis of covariance (ANCOVA) to test the effects of run (run 1, run 2), light treatment (light, dark), and source (leaves, maize, dung) with initial DOC concentrations as covariate on DOC uptake parameters (uptake rate, T50), followed by Bonferroni tests to distinguish between the different sources. We performed Pearson's correlation tests to determine the relationship among DOC uptake parameters, initial DOC and nutrients concentrations, and DOM quality parameters, such as BIX, Coble peaks, and PARAFAC components. A principal component analysis (PCA) was used to reduce the number of DOM composition variables and identify temporal patterns of spectroscopic variables among sources. Changes in biofilm properties were checked with $t$-tests. Results at $p<0.05$ were considered significant. All statistical analyses were performed in IBM SPSS Statistics 24.0 (IBM Corporation 2016, New York, NY, USA). 


\section{Results}

\subsection{Changes in Hydrochemistry by Leachate Additions}

We defined the water samples collected four hours after the leachate additions as initial DOC and nutrient concentrations. The leachate additions achieved a general increase in DOC concentrations from 1.4-2.4 $\mathrm{mg} \mathrm{L}^{-1}$ background conditions to 6.4-8.9 $\mathrm{mg} \mathrm{L}^{-1}$ four hours after the addition (Table 2). The only exception were the dark flumes in run 1, where the initial DOC concentrations reached only 4.8-5.7 $\mathrm{mg} \mathrm{L}^{-1}$ during the first sampling and were thus approximately $25 \%$ lower than in the light flumes at the same time. During the experiments, we observed an increase in DOC concentrations in the control flumes by $1-1.3 \mathrm{mg} \mathrm{L}^{-1}$ (run 1) and $0.2-0.3 \mathrm{mg} \mathrm{L}^{-1}$ (run 2), indicating a general net DOC production in the flumes when no leachates were added.

Table 2. Initial water chemistry and selected spectroscopic data of the flume water four hours after the leachate additions (Cont = control flumes; maize, leaf, and dung = flumes with leachate additions of these sources; - below detection limit; means and standard deviations in brackets).

\begin{tabular}{|c|c|c|c|c|c|c|c|c|c|}
\hline & \multirow[b]{2}{*}{ Runs } & \multicolumn{4}{|c|}{ Light } & \multicolumn{4}{|c|}{ Dark } \\
\hline & & Cont & Maize & Leaf & Dung & Cont & Maize & Leaf & Dung \\
\hline DOC $^{1}$ & 1 & $1.9(0.1)$ & $8.9(1.9)$ & $7.3(0.4)$ & $7.1(0.9)$ & $2.4(0.1)$ & $5.0(0.3)$ & $4.8(0.9)$ & $5.7(0.5)$ \\
\hline $\mathrm{NH}_{4}-\mathrm{N}$ & 1 & - & $7.5(0.4)$ & $7.7(3.3)$ & $30.9(11)$ & - & $8.5(0.1)$ & $15.2(2.1)$ & $46.0(2.1)$ \\
\hline$\mu \mathrm{g} \mathrm{L}^{-1}$ & 2 & - & $8.2(2.1)$ & $9.1(4.3)$ & $13.7(11)$ & - & $7.9(0.9)$ & $32.2(1.9)$ & $150.8(6)$ \\
\hline \multirow{2}{*}{$\mathrm{C} 1(\%)^{2}$} & 1 & 29.1 & 33.3 & 28.1 & 30.6 & 24.9 & 27.6 & 27.2 & 28.0 \\
\hline & 2 & 31.8 & 26.6 & 30.5 & 29.4 & 28.2 & 23.0 & 22.6 & 23.2 \\
\hline \multirow{2}{*}{ C2 (\%) } & 1 & 45.1 & 38.8 & 44.1 & 42.9 & 41.7 & 35.6 & 36.0 & 35.1 \\
\hline & 2 & 37.1 & 44.4 & 41.9 & 44.8 & 34.2 & 38.1 & 39.8 & 40.1 \\
\hline \multirow{2}{*}{ C3 (\%) } & 1 & 5.1 & 7.1 & 5.7 & 7.1 & 8.0 & 12.6 & 10.5 & 13.5 \\
\hline & 2 & 8.9 & 7.8 & 8.7 & 8.0 & 14.6 & 10.5 & 10.1 & 11.2 \\
\hline SUVA $254^{3}$ & 2 & 4.7 & 1.3 & 2.4 & 2.1 & 4.3 & 1.6 & 2.0 & 1.8 \\
\hline \multirow{2}{*}{ E2:E3 ${ }^{4}$} & 1 & 5.54 & 12.6 & 10.6 & 9.6 & 5.8 & 8.3 & 8.0 & 9.0 \\
\hline & 2 & 7.73 & 5.6 & 5.6 & 5.3 & 7.1 & 5.6 & 5.7 & 6.6 \\
\hline \multirow{2}{*}{$\mathrm{HIX}^{5}$} & 1 & 0.58 & 0.66 & 0.61 & 0.67 & 0.58 & 0.64 & 0.61 & 0.65 \\
\hline & 2 & 0.66 & 0.60 & 0.64 & 0.61 & 0.67 & 0.59 & 0.58 & 0.62 \\
\hline \multirow{2}{*}{ FIX $^{6}$} & 1 & 1.63 & 1.71 & 1.71 & 1.71 & 1.65 & 1.60 & 1.65 & 1.59 \\
\hline & 2 & 1.72 & 1.60 & 1.63 & 1.61 & 1.57 & 1.59 & 1.59 & 1.60 \\
\hline \multirow{2}{*}{ BIX $^{7}$} & 1 & 1.15 & 0.95 & 1.00 & 1.03 & 1.10 & 1.10 & 1.12 & 1.06 \\
\hline & 2 & 0.92 & 1.13 & 1.11 & 1.05 & 1.03 & 1.10 & 1.12 & 1.06 \\
\hline
\end{tabular}

${ }^{1}$ Dissolved organic carbon; ${ }^{2}$ C1-C4 = PARAFAC components (see Table 1 ); ${ }^{3}$ specific UV absorbance at 254 nm;

${ }^{4}$ ratio of absorbance at $250 \mathrm{~nm}$ to that at $365 \mathrm{~nm} ;{ }^{5}$ humification index; ${ }^{6}$ fluorescence index; ${ }^{7}$ biological index [56].

SRP concentrations were usually below the detection limit before the additions and increased to 17-95 $\mu \mathrm{g} \mathrm{L}-1$ on average in the dark flumes after the additions (Figure 1). The lowest SRP concentrations were observed in the dung treatment. Peaks were twice as high in run 2 as in run 1 . In the light flumes, SRP concentrations were mostly below the detection limit during the entire experiment. Initial DOP concentrations ranged between $35-103 \mu \mathrm{g} \mathrm{P} \mathrm{L}^{-1}$ in the dark treatments and between $0-45 \mu \mathrm{g} \mathrm{P} \mathrm{L}^{-1}$ in the light flumes (Figure 1). Both initial SRP and DOP concentrations declined within the first 1-2 days after the leachate additions, but increased again in most flumes towards the end of the experiments.

$\mathrm{NH}_{4}-\mathrm{N}$ concentrations were raised from below the detection limit before the additions to an average of $12 \mu \mathrm{g} \mathrm{L}^{-1} \mathrm{~N}$ in the maize and leaf treatments and an average of $60 \mu \mathrm{g} \mathrm{L}^{-1} \mathrm{~N}$ in the dung treatment after the leachate additions (Table 2). Similar to phosphorus, ammonium showed an initial decrease after the first peak, followed by partly increasing concentrations again during the experiment, although the patterns were inconsistent between treatments and sampling days. $\mathrm{NO}_{3}-\mathrm{N}$ concentrations ranged between 1.2 and $2.7 \mathrm{mg} \mathrm{L}^{-1}$ and were not affected by the leachate additions. Initial DON 
concentrations were low compared to the $\mathrm{NO}_{3}-\mathrm{N}$ concentrations $\left(35,50\right.$, and $150 \mu \mathrm{g} \mathrm{L}{ }^{-1}$ in leaf, maize, and dung flumes, respectively).
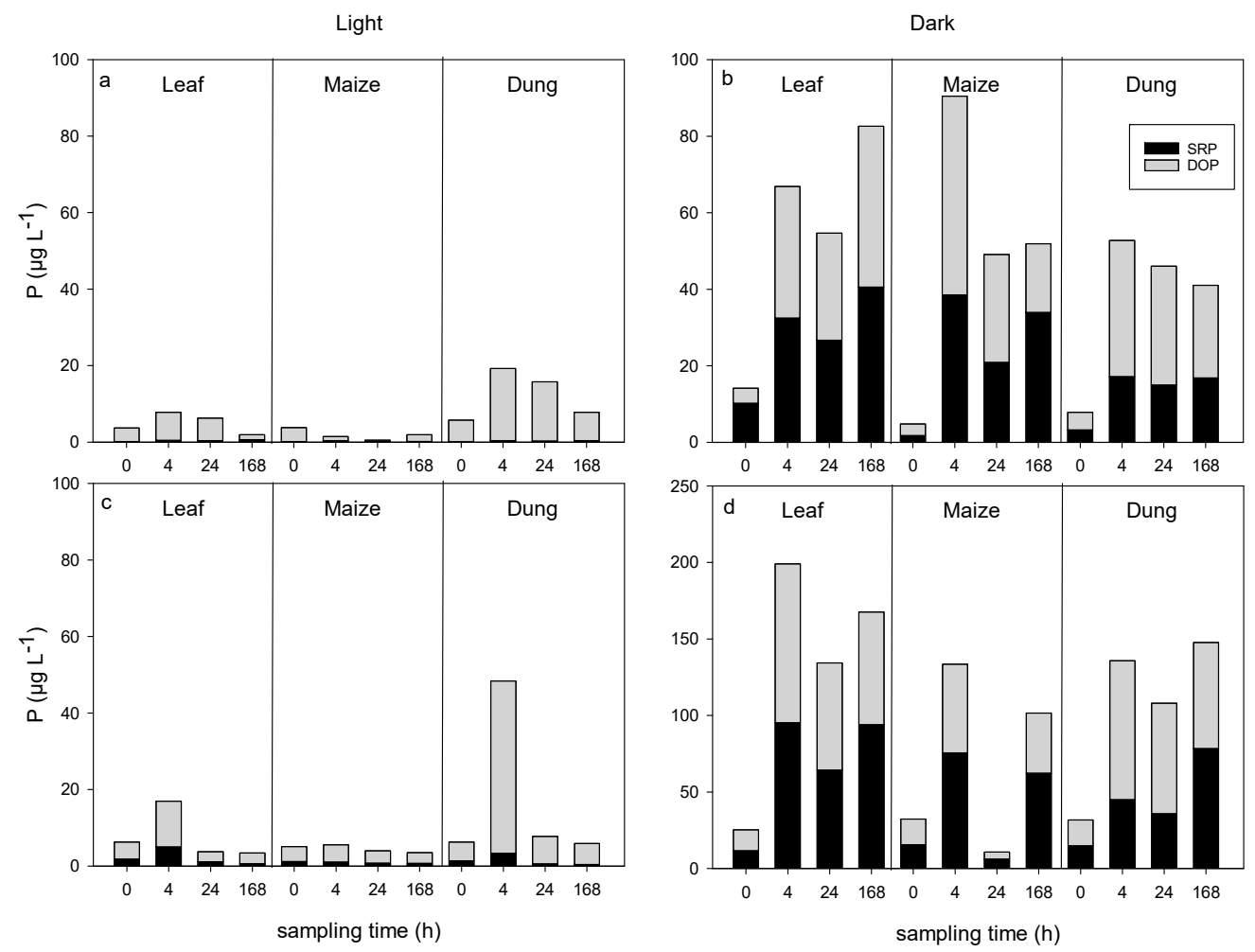

Figure 1. Changes in dissolved inorganic (SRP) and organic (DOP) phosphorus concentrations in the water column in leaf, maize, and dung treatments under light and dark conditions before ( 0 ) and 4, 24, and $168 \mathrm{~h}$ after the leachate additions during run $1(\mathbf{a}, \mathbf{b})$ and $2(\mathbf{c}, \mathbf{d})(n=3)$.

In general, the DOM components showed similar initial values within the same run and light treatments in both the control and the treatment flumes (Table 2). However, the humic-like C1 and the tryptophan-like $\mathrm{C} 2$ exhibited slightly higher proportions in the light flumes, while the humic-like, high-molecular $\mathrm{C} 3$ and the tyrosine-like $\mathrm{C} 4$ were more present in the dark flumes. Average initial SUVA $_{254}$ ranged from 1.6 (maize) to $2.5 \mathrm{~L} \mathrm{mg}^{-1} \mathrm{~m}^{-1}$ (leaves) in the treatment flumes and were thus significantly lower than in the control $\left(6.0 \mathrm{~L} \mathrm{mg}^{-1} \mathrm{~m}^{-1}\right)$. None of the other fluorescence or absorbance indices showed any differences or patterns among the flumes four hours after the leachate additions.

\subsection{DOC Uptake and Changes in DOM Composition}

Across all experiments, the ANCOVA yielded significant effects of the factors "run" $(p=0.000)$ and "source" $(p=0.000)$, but not "light", on both uptake rates and T50 $(n=36)$. All interactions were highly significant $(p=0.000)$. Due to the strong influence of "run" on the model results, we separated the two experimental runs for all further analyses. In run 1, both "source" and "light" showed significant effects on uptake rates and T50, while neither the initial DOC concentrations nor the interaction between "source" and "light" affected the DOC uptake significantly (Table 3). In run 2, only "source" affected the uptake significantly, but we found a significant interaction between the factors "light" and "source". Bonferroni tests yielded significant differences of both uptake rates and T50 between dung and the other two sources (leaves and maize) for both runs $(p<0.05)$.

In general, DOC uptake rates were higher by two to four times in run 2 than in run 1, especially in the dark flumes (Figure 2). Furthermore, run 1 showed significantly higher uptake rates in the light than in the dark flumes, while we could not observe any consistent light effects in run 2 (Table 3). Uptake rates of leaf and dung DOM followed the patterns observed in run 1 with higher values in the light flumes ( $p<0.05$ and $p>0.05$ for leaf and dung DOM, respectively). In contrast, maize DOM 
showed the fastest uptake of all under dark conditions in run $2(p<0.01 ; n=6)$. Independent of the light availability and the run, maize leachate was always slightly, though not significantly, faster taken up than leaf leachate, while dung leachate always showed a significantly slower uptake than the

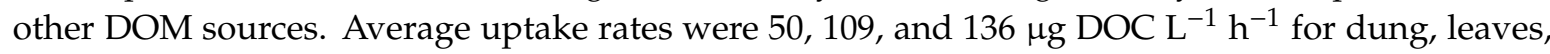

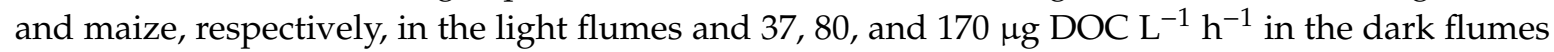
(Figure 2). After the first sharp decrease in DOC, all uptake curves levelled off at a higher DOC level than before the additions. After 7 days, maize, leaf, and dung leachates were reduced to 33, 39, and 54\% on average, respectively, in the light flumes and to 31,50 , and $51 \%$ on average in the dark flumes. Photodegradation amounted to less than $1 \%$ of the DOC loss in the light flumes during the first $24 \mathrm{~h}$ and was thus considered negligible.

Table 3. Results of the ANCOVA regarding the effects of source (leaf, maize, dung), light (light, dark), and initial DOC concentrations on the DOC uptake rate and T50 (time until 50\% DOC degradation). Shown are degrees of freedom (df), $F$-values, and probabilities ( $p$; significant differences are marked in bold; $n=18$ per run).

\begin{tabular}{cccccccccccc}
\hline & \multicolumn{4}{c}{ Run 1 } & \multicolumn{5}{c}{ Run 2 } \\
\hline & \multicolumn{4}{c}{ Rate } & \multicolumn{2}{c}{ T50 } & \multicolumn{2}{c}{ Rate } & \multicolumn{2}{c}{ T50 } \\
\hline & df & $\boldsymbol{F}$ & $\boldsymbol{p}$ & $\boldsymbol{F}$ & $\boldsymbol{p}$ & $\boldsymbol{F}$ & $\boldsymbol{p}$ & $\boldsymbol{F}$ & $\boldsymbol{p}$ \\
\hline Model & 6 & 17.3 & $\mathbf{0 . 0 0 0}$ & 23.3 & $\mathbf{0 . 0 0 0}$ & 81.6 & $\mathbf{0 . 0 0 0}$ & 39.0 & $\mathbf{0 . 0 0 0}$ \\
DOC & 1 & 0.9 & 0.347 & 0.2 & 0.632 & 13.6 & $\mathbf{0 . 0 0 4}$ & 0.4 & 0.539 \\
Source & 1 & 28.4 & $\mathbf{0 . 0 0 0}$ & 44.8 & $\mathbf{0 . 0 0 0}$ & 110.6 & $\mathbf{0 . 0 0 0}$ & 36.2 & $\mathbf{0 . 0 0 0}$ \\
Light & 2 & 4.9 & $\mathbf{0 . 0 4 8}$ & 9.4 & $\mathbf{0 . 0 1 1}$ & 1.9 & 0.199 & 2.4 & 0.148 \\
Light $\times$ Source & 2 & 0.8 & 0.482 & 0.2 & 0.862 & 52.2 & $\mathbf{0 . 0 0 0}$ & 18.1 & $\mathbf{0 . 0 0 0}$ \\
\hline
\end{tabular}

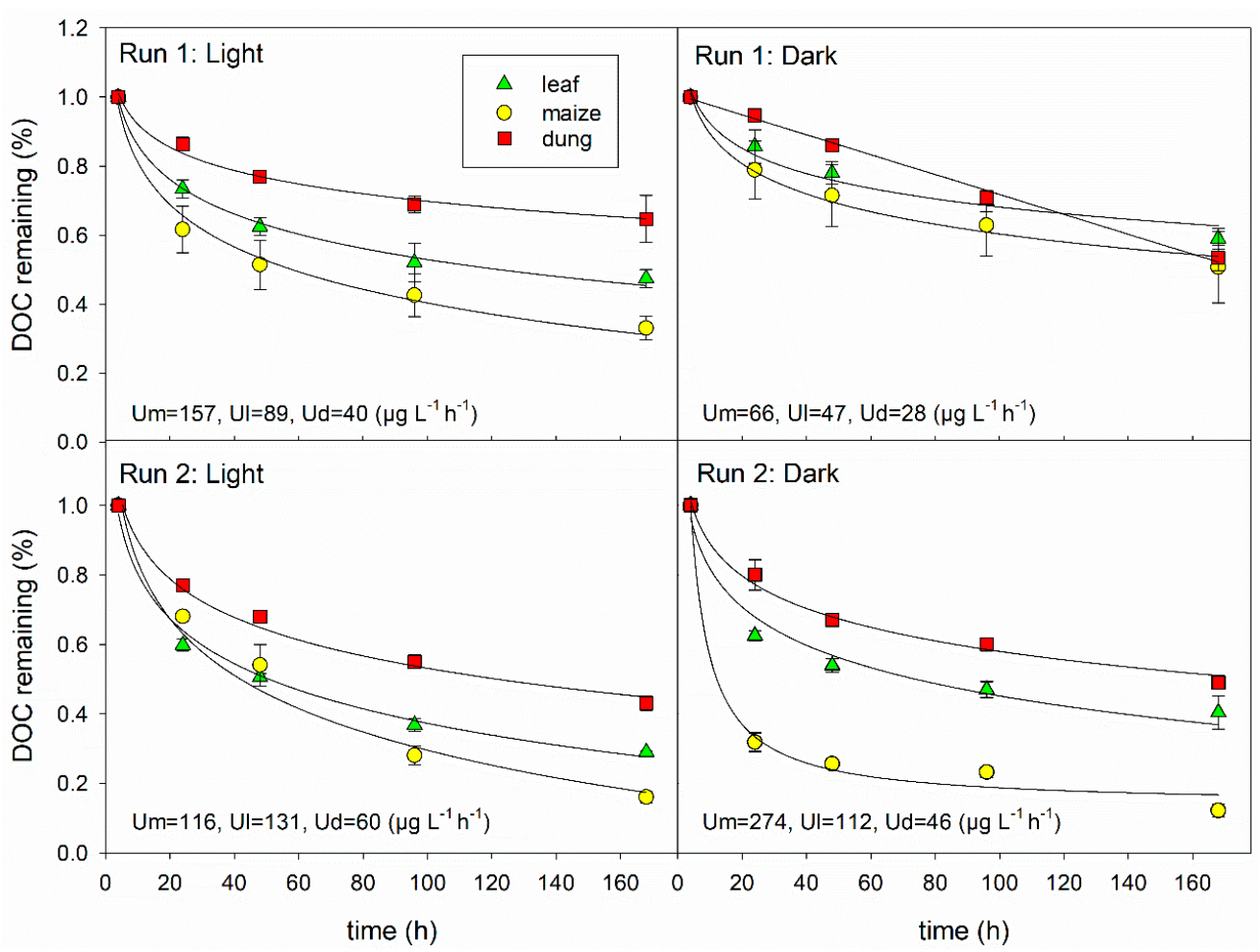

Figure 2. Dissolved organic carbon (DOC) uptake curves for leaf, maize, and dung leachates in light and dark flumes during run 1 and run 2 (DOC as relative proportion remaining). Shown are DOC concentrations in the water column per time (means and standard deviations, $n=3$ ), fitted uptake curves, and initial uptake rates (U) during the first $20 \mathrm{~h}$ for maize (Um), leaf (Ul), and dung leachates (Ud).

In both runs, DOC uptake rates were positively correlated with DOC $(p<0.001)$ and SRP $(p<0.04)$ concentrations and negatively with $\mathrm{NH}_{4}-\mathrm{N}(p<0.05)$ concentrations of the leachates (Pearson, $n=18$ 
per experiment). In addition, uptake rates were positively correlated with the initial values of $C 1$ and peaks $\mathrm{t}, \mathrm{a}$, and $\mathrm{m}$ in run 1 , and negatively with $\mathrm{C} 3$ and the $\mathrm{BIX}(p<0.05)$. In run 2 , uptake rates were additionally correlated negatively with the initial slope ratio $(p<0.05)$.

The first two principal components (PC) of the PCA explained $48.9 \%$ of the total variance. PC1 (26.4\%) showed strong positive loadings for parameters linked to terrestrial, humic-like material, such as the high-molecular terrestrial C3, the c-peak, HIX, and SUVA 254 , while BIX scored slightly negatively (Figure 3). PC2 (22.5\%) showed high positive scores for the tryptophan-like C2, the t-peak, and BIX, representing tryptophan-like, microbially derived material, and negative scores for DOC. The leachate additions shifted the DOM composition in the water column towards reduced BIX and HIX values independent of the source or the light conditions, revealing the distinct differences of spectroscopic properties between the DOM established in the water column and any of the freshly produced leachates (Figure 3b,c). In general, maize treatments showed smaller spectroscopic changes induced by the addition and a faster recovery to pre-addition levels than the other sources. Besides, light and dark treatments of the maize leachate exhibited similar patterns in each of the runs, indicating that the change of the DOM composition during the experiment was due to the respective DOM properties rather than to the community composition. In the leaf and dung treatments, indicators of freshness, such as the BIX, the tryptophan-like C2, and the tyrosine-like C4, often did not fully recover until the end of the experiments (especially in the dark flumes), while indicators of humification (HIX) increased to levels even above the pre-addition state (Figure 3b,c). Especially in run 1, changes in the spectroscopic properties differed between light conditions in both leaf and dung treatments, indicating that the community composition also affected the changes of DOM composition there. While the control was relatively stable throughout run 2 , the spectroscopic properties showed similar changes as the treatments in run 1 (Figure $3 b, c)$.

Overall, the humic-like C1 and C3 as well as BIX, HIX, SUVA 254 , and E2:E3 decreased after the addition and either remained reduced (leaf and dung; SUVA $_{254}$ for all sources) or increased to or above pre-addition levels during the experiments (maize; HIX for all sources). In contrast, the tryptophan-like $\mathrm{C} 2$ and peak $\mathrm{t}$ showed a gradual increase over the entire experiment, which was most pronounced in leaf and dung flumes. The tyrosine-like C4 showed the reverse pattern to C1 and C3 with a strong increase due the addition and a gradual decrease until the end of the experiment. In the control, we observed a slight increase in BIX and a slight decrease in HIX.

\subsection{Changes in Epipsammic and Epilithic Biofilm Properties}

Both epipsammic and epilithic biofilms of the dark flumes showed low organic matter contents throughout the experiments $\left(0.02-0.04 \mathrm{mg} \mathrm{cm}^{-2}\right.$ and $0-0.01 \mathrm{mg} \mathrm{cm}^{-2}$, respectively) and chlorophyll-a concentrations were below detection limit. In the epilithic biofilms of the light flumes, POM concentrations increased in both runs between day 0 and day 7 , whereby the biomass gains were larger in run 1 (Figure 4). There, POM concentrations ranged between 0.05 and $0.07 \mathrm{mg} \mathrm{cm}^{-2}$ on day 0 and between 0.09 and $0.15 \mathrm{mg} \mathrm{cm}^{-2}$ on day 7. In run 2, initial POM concentrations were slightly higher $\left(0.04-0.11 \mathrm{mg} \mathrm{cm}^{-2}\right)$, but increases were smaller than in run $1\left(0.07-0.13 \mathrm{mg} \mathrm{cm}^{-2} \mathrm{on}\right.$ day 7). The highest increases in POM concentrations were observed in the dung treatments in both runs, while the control showed the smallest increases, respectively. None of the differences were significant. Chlorophyll-a concentrations increased in the epilithic biofilms in all light flumes from $0.43-0.59 \mu \mathrm{g} \mathrm{cm}^{-2}$ to $1.01-1.65 \mu \mathrm{g} \mathrm{cm}^{-2}$ during run 1, whereby the highest increase was observed in the leaf treatment (growth rates of $0.07,0.09,0.09$, and $1.15 \mu \mathrm{g} \mathrm{chl-a} \mathrm{cm}{ }^{-2} \mathrm{~d}^{-1}$ for control, maize, dung, and leaves, respectively; Figure 4). Differences were significant for leaf, maize, and dung ( $t$-test, $p<0.05, n=12)$. During run 2, the initial chlorophyll-a concentrations were generally lower $(0.22-0.48$ $\mu \mathrm{g} \mathrm{cm}^{-2}$ ) and exhibited a higher variability than in run 1 . Only the control and the maize treatments showed a slight increase in chlorophyll-a concentrations by approximately $0.01 \mu \mathrm{g} \mathrm{chl-a} \mathrm{cm}{ }^{-2} \mathrm{~d}^{-1}$, whereas the concentrations even decreased in the leaf and dung treatments by $0.01-0.03 \mu \mathrm{g} \mathrm{cm}^{-2} \mathrm{~d}^{-1}$, respectively. Thus, the initial relation of chlorophyll-a to total POM was twice as high in run 1 than in 
run 2 and increased further until day 7, while it remained stable or decreased in run 2. We observed no differences in the algal community composition among sources and runs. Periphyton communities were dominated by diatoms ( $70-80 \%)$, while proportions of chlorophyta amounted to approximately $20 \%$ and those of cyanobacteria were below $5 \%$.
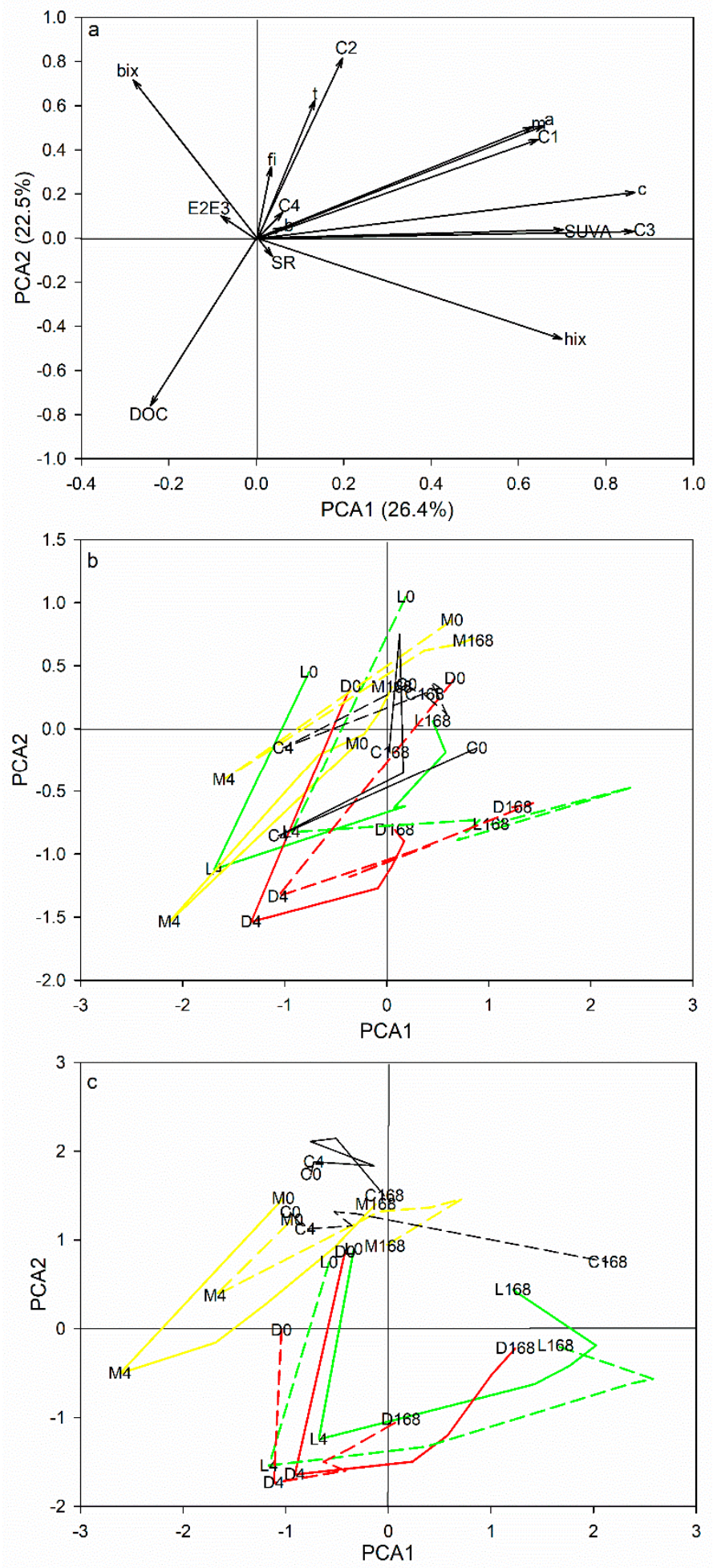

Figure 3. Principal component analysis (PCA) scores plot (a) and loadings plots for run 1 (b) and run 2 (c) for DOC concentrations and spectroscopic parameters. Points represent replicate means $(n=3)$ for each source, day, and light treatment; colors represent sources (green = leaf, yellow = maize, red = dung), line styles represent light conditions (solid = light, dotted = dark), letters represent source and day ( $\mathrm{L}=$ leaf, $\mathrm{M}=$ maize, $\mathrm{D}=$ dung; times: 0 (before) and 4 and $168 \mathrm{~h}$ after the addition). 


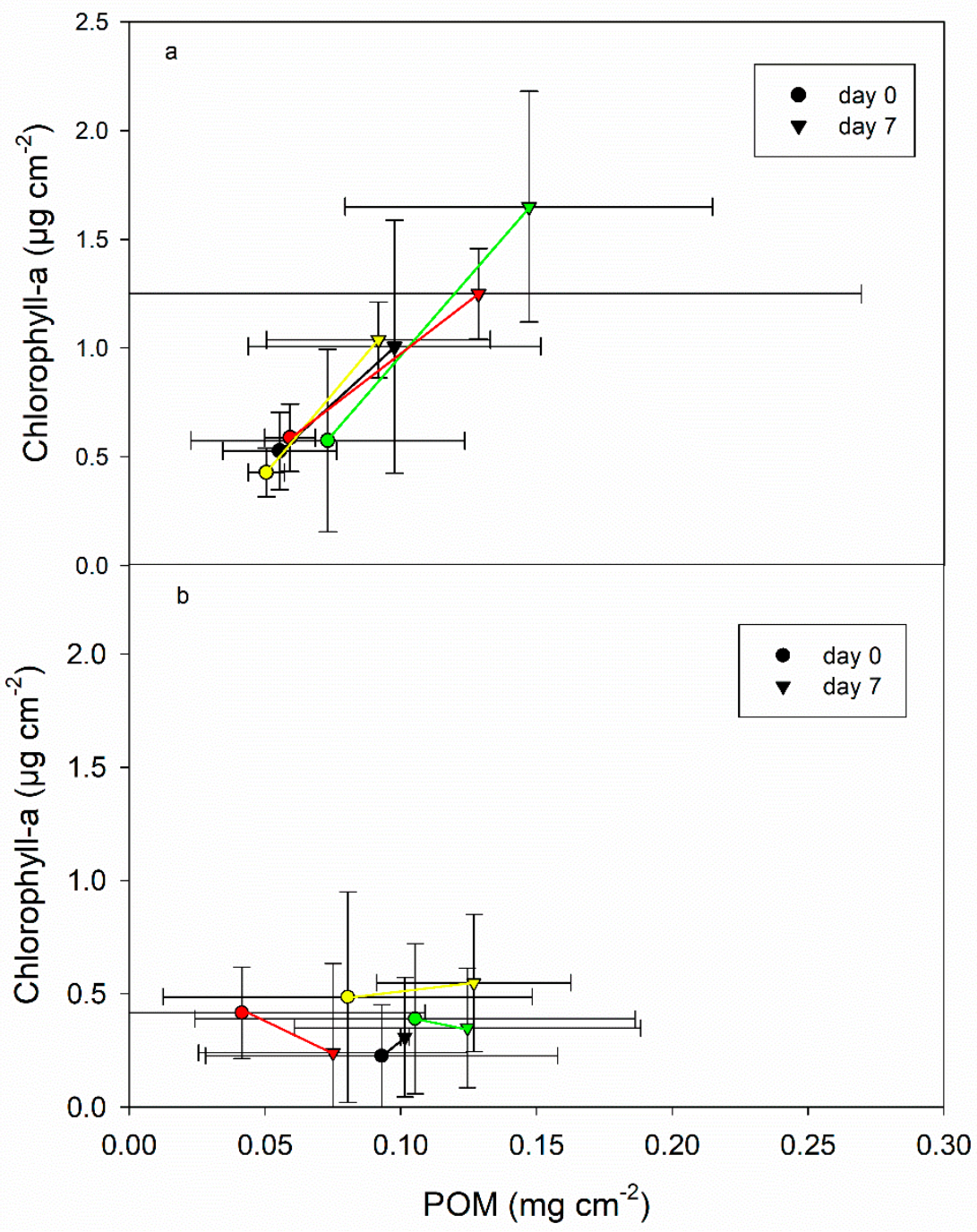

Figure 4. Changes in the organic matter (POM) and chlorophyll-a concentrations in the epilithic biofilms of the light flumes during run 1 (a) and run 2 (b) between day 0 and day 7 . Colors represent sources (black $=$ control, green $=$ leaf, yellow $=$ maize, red $=$ dung (means and standard deviations, $n=4-6)$.

Mean bacterial abundances in epipsammic biofilms were more than twice as high in run 1 than in run $2\left(126 \times 10^{6}\right.$ vs. $59 \times 10^{6}$ cells cm$^{-2}$, respectively; $t$-test, $\left.p<0.05, n=88\right)$. We observed no significant differences among treatments or between days 0 and 7 . Bacterial abundances in epilithic biofilms ranged from $1 \times 10^{4}-4.4 \times 10^{4}$ cells cm $\mathrm{cm}^{-2}$ and showed no significant differences between the two runs. In general, bacterial abundances were lowest in the control and the maize treatment $\left(1.5 \times 10^{4}\right.$ and $1.7 \times 10^{4}$ cells cm${ }^{-2}$, respectively), intermediate in the dung treatment $\left(2.9 \times 10^{4} \mathrm{cells} \mathrm{cm}^{-2}\right)$ and highest in the leaf treatment $\left(4.3 \times 10^{4}\right.$ cells $\left.\mathrm{cm}^{-2}\right)$.

The activities of extra-cellular enzymes were higher in the light flumes than in the dark flumes (Figure 5). In the epipsammic biofilms, peptidase increased immediately after the additions and the water exchange in all flumes, whereby the increases were higher in the treatments than in the control. While the activities decreased again to pre-addition levels in the dark flumes, we observed further increases in the light flumes. Phosphatase activities showed no response to the additions under dark conditions. However, in the light flumes, phosphatase activities increased immediately after the additions, with further increases in run 1, similar to peptidase. Due to the low biomass, we could not measure any enzymatic activities in the epilithic biofilms of the dark flumes. In the light flumes, enzyme activities showed similar patterns as in the epipsammic biofilms. 


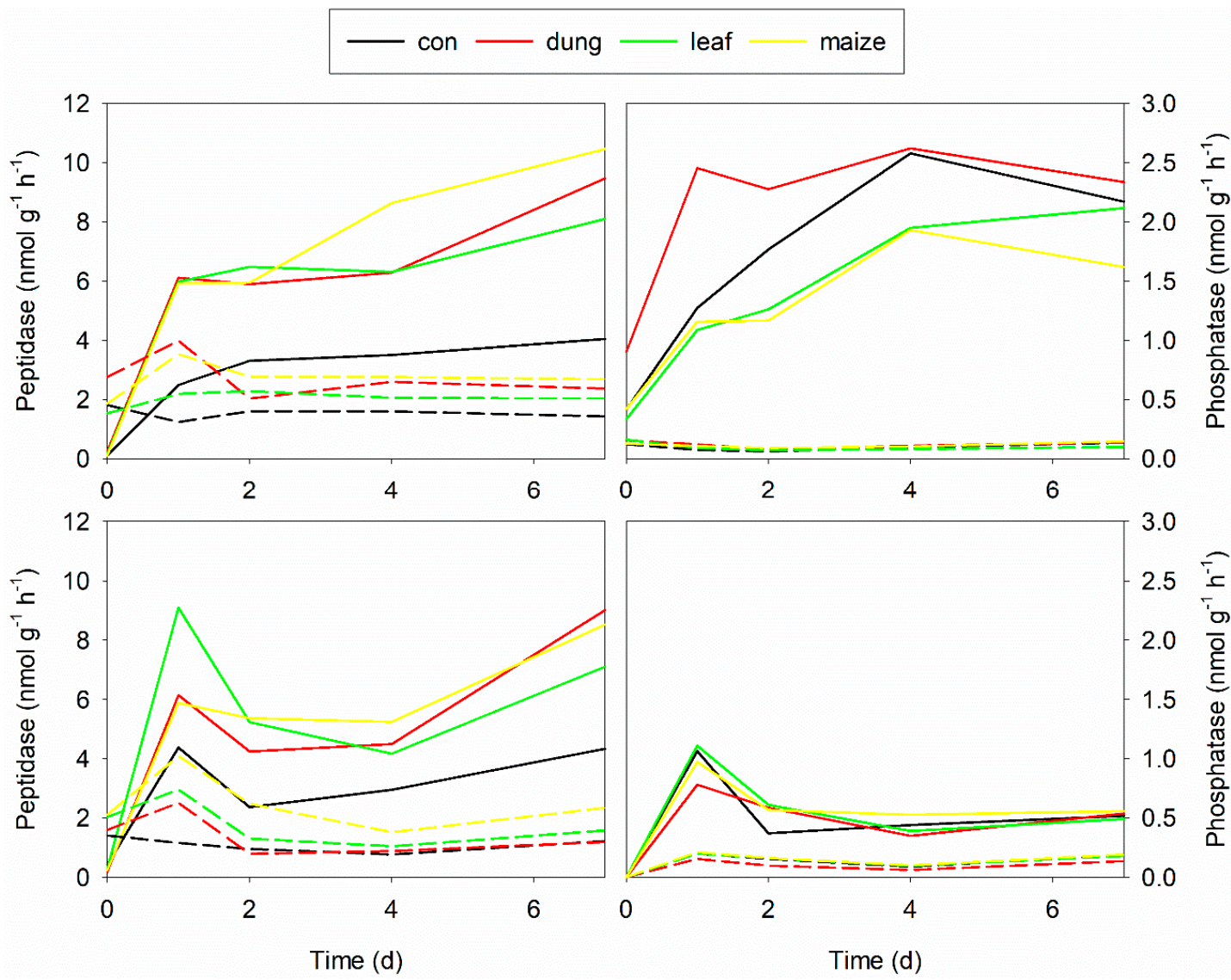

Figure 5. Average changes in the activity of leucine-aminopeptidase and phosphatase in epipsammic biofilms under light (solid lines) and dark (dotted lines) conditions (upper graph = run 1; lower graph $=$ run $2 ; n=6)$.

\section{Discussion}

\subsection{Effects of DOM Quality on DOM Degradation}

Independent of the biofilm community, the order of DOC degradation was always the same in our experiments, with uptake rates increasing from dung to leaf and maize leachates. We consider this an indication of the intrinsic control of organic matter degradation by DOM properties [12]. Correlation of DOC uptake with DOM properties has also been found by others, especially in degradation studies with homogeneous communities and under stable environmental conditions [9-11]. In our study, the strongest positive correlation was observed between DOC uptake and the initial SRP content of the leachates, indicating that phosphorus availability played a key role in the DOC degradation in our P-limited systems. In fact, the leachate additions could slightly lift the strong initial P-limitation (and C-co-limitation) in the flumes by changing the stoichiometric molar ratios of C:N:P from an average of 2830:2540:1 to 590:240:1 in the water column. Field investigations and inorganic nutrient addition experiments in streams confirm the key role of nutrient availability in the degradation of terrestrial organic carbon in stream ecosystems [2,21,24,25]. In addition to an external nutrient supply from various sources, such as waste water or fertilizers, the stoichiometric ratio of the carbon source itself can influence the DOC degradation [27]. Ref. [59], for example, observed a decline of the bacterial productivity with increasing C:P ratios of the studied DOC sources in an incubation experiment. In contrast to SRP, $\mathrm{NH}_{4}-\mathrm{N}$ showed an unexpected negative correlation with DOC uptake in our study. So far, we have not found any evidence in the literature about inhibitory effects of ammonium on DOC degradation. Thus, we think that this negative correlation may result from the fact that dung leachate had the highest ammonium concentration, but was least degraded. 
In addition to SRP, the initial DOC concentrations played an important role in the DOC uptake in our experiments, resulting in increased uptake rates at higher initial concentrations and negative logarithmic uptake curves. These findings are consistent with nutrient uptake kinetic models, where uptake rates are expected to increase with increasing concentrations of the respective substance as long as the system does not approach saturation (e.g., [60,61]). Indeed, most DOC degradation studies show negative exponential uptake curves similar to inorganic nutrients, where uptake rates are highest at high DOC concentrations $[9,10,12,25,62]$. Like in our study, these curves often level off at DOC concentrations above the original background, indicating either the existence of refractory components [10,62] or the establishment of renewed nutrient-limiting conditions for DOC degradation.

Interestingly, we found only subtle and sometimes conflicting effects of the spectroscopic properties of the leachates on the respective DOC uptake. Against our expectations, BIX correlated negatively with uptake rates in run 1, although this index is considered to represent freshly produced material of microbial origin and should thus stimulate DOC uptake [12]. Indeed, several studies have demonstrated a high uptake of protein-like, fresh components during DOC degradation [9,10,40]. In contrast, ref. [13] found no evidence for the influence of DOM composition on the in-stream DOC uptake in a comparative field study, which they explained by environmental factors influencing the activity of the microbial community. We explain our findings by the fact that spectroscopic data were measured only four hours after the addition. This was done to ensure complete mixing of the leachates within the flumes, but naturally allowed for both the degradation of the added DOC and the production of new DOC, e.g., through the stimulation of algae by the added phosphorus. Evidence for a fast turnover of the added leachates in our experiments is the complete uptake of the phosphorus from the water column within the first four hours in the light flumes.

Changes in the DOM composition during degradation indicate a co-occurrence of both microbial DOM degradation and production in our flumes. This makes degradation patterns hard to interpret, especially in complex benthic systems with both autotrophic and heterotrophic micro-organisms involved. The complexity of DOM degradation has also been highlighted by [12], who observed opposing effects of biodegradation and photodegradation on changes in the DOM composition. In their comparison of various DOM sources, the character of the DOM moved from a fresh-like to a more humic-like fluorescence signal during biodegradation, while photodegradation reversed this trend. Besides, spectroscopy captures only part of the DOM and both indices and components are supposed to represent certain molecule groups, but detailed information about changes on molecular base are actually lacking. Thus, more detailed analyses of molecule groups, such as carbohydrates, proteins, and lipids, are needed to identify the various processes responsible for changes in the DOM composition during microbial processing [63].

\subsection{Effects of Biofilm Composition on DOM Degradation}

In addition to the observed intrinsic control of DOM degradation, we also found evidence for external control factors, such as the composition and activity of the biofilm. Heterotrophic DOC uptake was clearly stimulated by the presence of algae in run 1, but we also observed slight positive effects of algae in the leaf and dung treatments in run 2. Algal stimulation of OM degradation has been reported in planktonic and benthic systems for both particulate and dissolved organic matter, although the exact mechanisms behind such a stimulation are still unclear. Priming has been proposed as a key factor for the stimulation of POM decomposition by periphytic algae [64-66]. Here, the presence of labile DOM components, such as algal exudates, is assumed to enhance the microbial breakdown of more recalcitrant organic compounds [67]. However, studies about priming effects in aquatic systems diverge. Ref. [68], for example, observed that algal DOM improved the degradation of refractory peat DOM in leachate incubations, while [20,69] found no evidence for priming effects in hyporheic biofilms and lake water, respectively. Some studies report on the influence of nutrient availability on the priming of organic matter decomposition, with higher nutrient concentrations reducing [66,70] or enhancing [65] the priming effect of algal exudates. Finally, there are also studies reporting on competitive effects 
between algal and terrestrial DOM. Ref. [32] observed that benthic biofilms tended to respire more autochthonous than allochthonous DOC during high light availability. Thus, bacteria may prefer algal DOM over more recalcitrant terrestrial carbon sources (see also [70]). Although light-grown biofilms were mostly net DOC consumers, ref. [34] observed an internal recycling of high quality DOM within those communities, while dark-grown biofilms were more dependent on the external DOC supply.

Other hypotheses for the stimulating effects of algae on bacterial DOM degradation focus more on the environmental conditions provided by the presence of algae than on actual priming effects. During photosynthesis, algae increases the $\mathrm{pH}$ and the redox potential to conditions optimal for enzymatic reactions, thereby probably enhancing organic matter degradation [37,64]. Enhanced enzymatic activities in light-grown biofilms, which are related to $C$ degradation, were found in our study as well as in others $[35,71]$. Finally, algae may change the nutrient availability. In our study, the fast decrease in P concentrations during the first four hours after the additions, which only occurred in the light flumes, indicates that algae outcompeted bacteria in P uptake. Algae are able to store excess $\mathrm{P}$, enabling them to react quickly to short-term $\mathrm{P}$ supply in P-limited systems. However, we also observed an increase in phosphatase activities as well as a secondary slight increase in SRP concentrations during the experiments, indicating that the added $\mathrm{P}$ was recirculated fast or that new $\mathrm{P}$ was produced through bacterial mineralization.

Despite our efforts to establish the same conditions in run 2 as in run 1, the two runs differed. The most apparent differences were observed in the concentrations of the added leachates (slightly higher DOC and significantly higher SRP concentrations in run 2) and in the activity of the epilithic biofilms. In run 1, increases in biomass and chlorophyll-a concentrations between days 0 and 7 reveal the existence of a young, still developing epilithic biofilm. In contrast, biomass gains were lower in run 2 and chlorophyll-a concentrations even declined in some of the flumes, indicating a more aged and eventually degrading epilithic biofilm. In fact, biofilms in run 2 developed from the remaining biofilms of run 1 thus showing a similar composition, but a higher age. The reduced algal activities may have resulted in smaller positive effects of algae on microbial DOM uptake. Further systematic studies are needed on the effects of autotrophic-heterotrophic interactions on DOM degradation considering also their physiological state.

Based on the results of our study, we have developed a concept about the interplay of controlling factors for DOM degradation (Figure 6). Primarily, DOM degradation is determined by the DOM source itself. Concentrations of DOC and co-leached $\mathrm{N}$ and $\mathrm{P}$ as well as the proportions of different DOM components control the degradation of the pure DOM source. These intrinsic determinants can be overlaid by external physico-chemical factors in the environment, such as the nutrient availability, $\mathrm{pH}$, light, and temperature conditions in the aquatic system. As a result, DOM components may shift in their degradability to a higher or lower degree of recalcitrance. We expect DOM components with a moderate degradability to be more prone to such shifts than components of extremely high or low recalcitrance. Finally, the community acts as a biotic filter, which controls the magnitude and direction of the effects of both the DOM source and the environment on the DOM degradation. Here, we expect stronger filtering effects by communities subject to intense internal cycling (e.g., autotrophic biofilms) than those depending on external $\mathrm{C}$ and nutrient supply (e.g., bacterioplankton and heterotrophic biofilms). Additionally, transport limitations in clogged sediments or thick biofilms may restrict the exchange between the DOM and the reactive sites [48].

Dissolved organic carbon is a key component in streams' metabolism and functioning, but has been changed severely in both quantity and quality during the last decades due to intensive human land use. While batch experiments give close insight into the degradability of different DOM sources under controlled conditions, more studies are needed about the role and fate of autochthonous and allochthonous DOM within different stream communities [72]. Specifically, interactions among different organisms, potential transport limitations through biofilms, and non-additive effects of additional stressors, such as climate change, require systematic studies under conditions that are as realistic as possible to reveal the role and interplay of the different internal and external controlling factors on 
the aquatic DOM degradation. Despite numerous DOC uptake studies, the drivers of in-stream DOC uptake over time and across streams still remain unclear, which limits our ability to integrate the role of freshwaters in global biogeochemical cycles. Our results reinforce the idea that a better understanding, and representation in sampling schemes, of the main DOM sources is essential to mechanistically understand $\mathrm{C}$ processing rates in headwater streams.
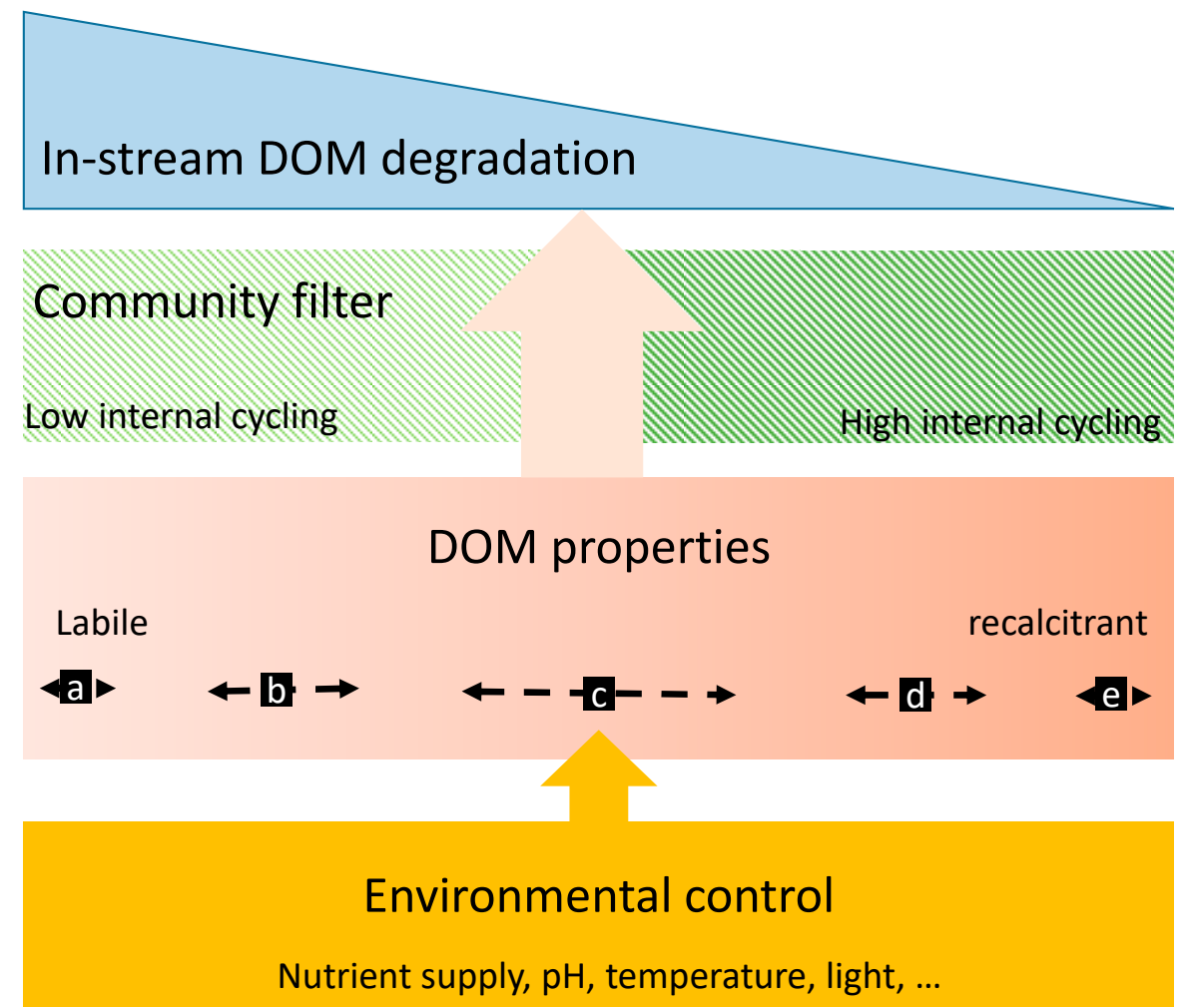

Figure 6. Concept of intrinsic (dissolved organic matter (DOM) properties) and external (environmental) controlling factors of aquatic DOM degradation, with microbial communities acting as a filter. Different DOM components (a-e) are expected to show a varying degree of degradability, ranging from highly labile (a) to highly recalcitrant (e), which may change due to the influence of the environment (indicated by the horizontal dashed arrows). The filter effect of the community is supposed to depend on the degree of internal cycling.

Author Contributions: Conceptualization, G.W.; Funding acquisition, G.W.; Investigation, T.S.J.; Methodology, G.S.; Project administration, G.W.; Resources, T.-C.Y., G.S. and M.P.; Supervision, G.W.; Writing-original draft, G.W.; Writing-review and editing, T.S.J., T.-C.Y., and M.P. All authors have read and agreed to the published version of the manuscript.

Funding: This study was funded by the Provincial Government of Lower Austria, NFB, within the Science Call 2015 (SC15-002; project ORCA).

Acknowledgments: Thanks to Ching-Hsuang Lo, Beate Pitzl, and Annette Puritscher for their support in the laboratory.

Conflicts of Interest: The authors declare no conflict of interest. The funders had no role in the design of the study; in the collection, analyses, or interpretation of data; in the writing of the manuscript, or in the decision to publish the results.

\section{References}

1. Gordon, L.J.; Peterson, G.D.; Bennett, E.M. Agricultural modifications of hydrological flows create ecological surprises. Trends Ecol. Evol. 2008, 23, 211-219. [CrossRef] [PubMed]

2. Ziegler, S.E.; Brisco, S.L. Relationships between the isotopic composition of dissolved organic carbon and its bioavailability in contrasting Ozark streams. Hydrobiologia 2004, 513, 153-169. [CrossRef] 
3. Bechtold, H.A.; Marcarelli, A.M.; Baxter, C.V.; Inouye, R.S. Effects of N, P, and organic carbon on stream biofilm nutrient limitation and uptake in a semi-arid watershed. Limnol. Oceanogr. 2012, 57, 1544-1554. [CrossRef]

4. Graeber, D.; Gelbrecht, J.; Pusch, M.T.M.T.; Anlanger, C.; von Schiller, D.; Schiller, D. Von Agriculture has changed the amount and composition of dissolved organic matter in Central European headwater streams. Sci. Total Environ. 2012, 438, 435-446. [CrossRef]

5. Stutter, M.I.; Graeber, D.; Evans, C.D.; Wade, A.J.; Withers, P.J.A. Balancing macronutrient stoichiometry to alleviate eutrophication. Sci. Total Environ. 2018, 634, 439-447. [CrossRef]

6. Wilson, H.F.; Xenopoulos, M.A. Effects of agricultural land use on the composition of fluvial dissolved organic matter. Nat. Geosci. 2009, 2, 37-41. [CrossRef]

7. Tiefenbacher, A.; Weigelhofer, G.; Klik, A.; Pucher, M.; Santner, J.; Wenzel, W.; Eder, A.; Strauss, P. Short-term effects of fertilization on dissolved organic matter in soil leachate. Water 2020, 12, 1617. [CrossRef]

8. Williams, C.J.; Yamashita, Y.; Wilson, H.F.; Jaffe, R.; Jaffé, R.; Xenopoulos, M. Unraveling the role of land use and microbial activity in shaping dissolved organic matter characteristics in stream ecosystems. Limnol. Oceanogr. 2010, 55, 1159-1171. [CrossRef]

9. Guillemette, F.; Del Giorgio, P.A. Reconstructing the various facets of dissolved organic carbon bioavailability in freshwater ecosystems. Limnol Ocean. 2011, 56, 734-748. [CrossRef]

10. Koehler, B.; Von Wachenfeldt, E.; Kothawala, D.; Tranvik, L.J. Reactivity continuum of dissolved organic carbon decomposition in lake water. J. Geophys. Res. Biogeosci. 2012, 117, 1-14. [CrossRef]

11. Berggren, M.; Giorgio, P.A. Distinct patterns of microbial metabolism associated to riverine dissolved organic carbon of different source and quality. J. Geophys. Res. Biogeosci. 2015, 120, 989-999. [CrossRef]

12. Hansen, A.M.; Kraus, T.E.C.; Pellerin, B.A.; Fleck, J.A.; Downing, B.D.; Bergamaschi, B.A. Optical properties of dissolved organic matter (DOM): Effects of biological and photolytic degradation. Limnol. Oceanogr. 2016, 61, 1015-1032. [CrossRef]

13. Lupon, A.; Catalán, N.; Marti, E.; Bernal, S. Influence of Dissolved Organic Matter Sources on In-Stream Net Dissolved Organic Carbon Uptake in a Mediterranean Stream. Water 2020, 12, 1722. [CrossRef]

14. Bernhardt, E.S.; McDowell, W.H. Twenty years apart: Comparisons of DOM uptake during leaf leachate releases to Hubbard Brook valley streams in 1979 versus 2000. J. Geophys. Res. Biogeosci. 2008, 113, 1-8. [CrossRef]

15. Berggren, M.; Laudon, H.; Haei, M.; Ström, L.; Jansson, M. Efficient aquatic bacterial metabolism of dissolved low-molecular-weight compounds from terrestrial sources. ISME J. 2010, 4, 408-416. [CrossRef]

16. Lane, C.S.; Lyon, D.R.; Ziegler, E. Cycling of two carbon substrates of contrasting lability by heterotrophic biofilms across a nutrient gradient of headwater streams. Aquat. Sci. 2013, 75, 235-250. [CrossRef]

17. Amon, R.M.W.; Benner, R. Bacterial utilization of different size classes of dissolved organic matter. Limnol. Oceanogr. 1996, 41, 41-51. [CrossRef]

18. Casas-Ruiz, J.P.; Catalán, N.; Gómez-Gener, L.; von Schiller, D.; Obrador, B.; Kothawala, D.N.; López, P.; Sabater, S.; Marcé, R. A tale of pipes and reactors: Controls on the in-stream dynamics of dissolved organic matter in rivers. Limnol. Oceanogr. 2017, 62, S85-S94. [CrossRef]

19. Schmidt, M.W.I.; Torn, M.S.; Abiven, S.; Dittmar, T.; Guggenberger, G.; Janssens, I.A.; Kleber, M.; Kögel-Knabner, I.; Lehmann, J.; Manning, D.A.C.; et al. Persistence of soil organic matter as an ecosystem property. Nature 2011, 478, 49-56. [CrossRef]

20. Bengtsson, M.M.; Wagner, K.; Burns, N.R.; Herberg, E.R.; Wanek, W.; Kaplan, L.A.; Battin, T.J. No evidence of aquatic priming effects in hyporheic zone microcosms. Sci. Rep. 2014, 4, 1-6. [CrossRef]

21. Brookshire, E.N.J.; Valett, H.M.; Thomas, S.A.; Webster, J.R. Coupled Cycling of Dissolved Organic Nitrogen and Carbon in a Forest Stream. Ecology 2005, 86, 2487-2496. [CrossRef]

22. Catalán, N.; Casas-Ruiz, J.P.; Arce, M.I.; Abril, M.; Bravo, A.G.; Del Campo, J.A.; Esteves, E.; Freixa, A. Behind the scenes: Mechanisms regulating climatic patterns of dissolved organic carbon uptake in headwater streams. Glob. Biogeochem. Cycles 2018, 32, 1528-1541. [CrossRef]

23. Berggren, M.; Laudon, H.; Jansson, M. Landscape regulation of bacterial growth efficiency in boreal freshwaters. Glob. Biogeochem. Cycles 2007, 21, 1-9. [CrossRef]

24. Rosemond, A.D.; Benstead, J.P.; Bumpers, P.M.; Gulis, V.; Kominoski, J.S.; Manning, D.W.P.; Suberkropp, K.; Wallace, J.B. Experimental nutrient additions accelerate terrestrial carbon loss from stream ecosystems. Freshw. Ecol. 2015, 347, 1142-1145. [CrossRef] 
25. Wickland, K.P.; Aiken, G.R.; Butler, K.; Dornblaser, M.M.; Spencer, R.G.M.; Striegl, R.G. Biodegradability of dissolved organic carbon in the Yukon River and its tributaries: Seasonality and importance of inorganic nitrogen. Glob. Biogeochem. Cycles 2012, 26, 1-14. [CrossRef]

26. Graeber, D.; Boëchat, I.G.; Encina-Montoya, F.; Esse, C.; Gelbrecht, J.; Goyenola, G.; Gücker, B.; Heinz, M.; Kronvang, B.; Meerhoff, M.; et al. Global effects of agriculture on fluvial dissolved organic matter. Sci. Rep. 2015, 5, 16328. [CrossRef]

27. Mutschlecner, A.E.; Guerard, J.J.; Jones, J.B.; Harms, T.K. Phosphorus Enhances Uptake of Dissolved Organic Matter in Boreal Streams. Ecosystems 2018, 21, 675-688. [CrossRef]

28. Stets, E.G.; Cotner, J.B. The influence of dissolved organic carbon on bacterial phosphorus uptake and bacteria-phytoplankton dynamics in two Minnesota lakes. Limnol. Oceanogr. 2008, 53, 137-147. [CrossRef]

29. Thingstad, T.F.; Bellerby, R.G.J.; Bratbak, G.; Børsheim, K.Y.; Egge, J.K.; Heldal, M.; Larsen, A.; Neill, C.; Nejstgaard, J.; Norland, S.; et al. Counterintuitive carbon-to-nutrient coupling in an Arctic pelagic ecosystem. Nature 2008, 455, 387-390. [CrossRef]

30. Oviedo-Vargas, D.; Royer, T.V.; Johnson, L.T. Dissolved organic carbon manipulation reveals coupled cycling of carbon, nitrogen, and phosphorus in a nitrogen-rich stream. Limnol. Oceanogr. 2013, 58, 1196-1206. [CrossRef]

31. Scott, J.T.; Back, J.A.; Taylor, J.M.; King, R.S. Does nutrient enrichment decouple algal—Bacterial production in periphyton? J. N. Am. Benthol. Soc. 2008, 27, 332-344. [CrossRef]

32. Wagner, K.; Bengtsson, M.M.; Findlay, R.H.; Battin, T.J.; Ulseth, A.J. High light intensity mediates a shift from allochthonous to autochthonous carbon use in phototrophic stream biofilms. J. Geophys. Res. Biogeosci. 2017, 122, 1806-1820. [CrossRef]

33. Demars, B.O.L.; Friberg, N.; Kemp, J.L.; Thornton, B. Reciprocal carbon subsidies between autotrophs and bacteria in stream food webs under stoichiometric constraints. bioRxiv 2018, 447987. [CrossRef]

34. Romaní, A.M.; Guasch, H.; Muñoz, I.; Ruana, J.; Vilalta, E.; Schwartz, T.; Emtiazi, F.; Sabater, S. Biofilm structure and function and possible implications for riverine DOC dynamics. Microb. Ecol. 2004, 47, 316-328. [CrossRef]

35. Rier, S.T.; Shirvinski, J.M.; Kinek, K.C. In situ light and phosphorus manipulations reveal potential role of biofilm algae in enhancing enzyme-mediated decomposition of organic matter in streams. Freshw. Biol. 2014, 59, 1039-1051. [CrossRef]

36. Rier, S.T.; Stevenson, R.J. Effects of light, dissolved organic carbon, and inorganic nutrients on the relationship between algae and heterotrophic bacteria in stream periphyton. Hydrobiologia 2002, 489, 179-184. [CrossRef]

37. Rier, S.T.; Kuehn, K.A.; Francoeur, S.N.; Rier, S.T.; Kuehn, K.A.; Francoeur, S.N. Algal regulation of extracellular enzyme activity in stream microbial communities associated with inert substrata and detritus Algal regulation of extracellular enzyme activity in stream microbial communities associated with inert substrata and detritus. J. N. Am. Benthol. Soc. 2007, 26, 439-449. [CrossRef]

38. Sobczak, W.V. Epilithic Bacterial Responses to Variations in Algal Biomass and Labile Dissolved Organic Carbon during Biofilm Colonization. J. N. Am. Benthol. Soc. 1996, 15, 143-154. [CrossRef]

39. Ziegler, S.E.; Lyon, D.R. Factors regulating epilithic biofilm carbon cycling and release with nutrient enrichment in headwater streams. Hydrobiologia 2010, 657, 71-88. [CrossRef]

40. Fellman, J.B.; Hood, E.; Edwards, R.T.; D'Amore, D.V. Changes in the concentration, biodegradability, and fluorescent properties of dissolved organic matter during stormflows in coastal temperate watersheds. J. Geophys. Res. 2009, 114. [CrossRef]

41. APHA. Standard Methods for the Examination of Water and Waste Water, 21th ed.; American Public Health Association: Washington, DC, USA, 2005.

42. McKnight, D.M.; Boyer, E.W.; Westerhoff, P.K.; Doran, P.T.; Kulbe, T.; Andersen, D.T.; Kulbe, E.W.; Boyer, P.K.; Westerhoff, P.T.; Doran, T.; et al. Spectroflourometric characterization of dissolved organic matter for indication of precursor organic material and aromaticity. Limnol. Oceanogr. 2001, 46, 38-48. [CrossRef]

43. Coble, P.G. Characterization of marine and terrestrial DOM in seawater using excitation-emission matrix spectroscopy. Mar. Chem. 1996, 51, 325-346. [CrossRef]

44. Kothawala, D.N.; Murphy, K.R.; Stedmon, C.A.; Weyhenmeyer, G.A.; Tranvik, L.J. Inner filter correction of dissolved organic matter fluorescence. Limnol. Oceanogr. Methods 2013, 11, 616-630. [CrossRef]

45. Duhamel, S.; Jacquet, S. Flow cytometric analysis of bacteria- and virus-like particles in lake sediments. J. Microbiol. Methods 2006, 64, 316-332. [CrossRef] [PubMed] 
46. Browne, J.L. Comparison of Chemotaxonomic Methods for the Determination of Periphyton Community Composition. Master's Thesis, Florida Atlantic University, Florida, FL, USA, 2010.

47. Greisberger, S.; Teubner, K. Does pigment composition reflect phytoplankton community structure in differing temperature and light conditions in a deep alpine lake? An approach using hplc and delayed fluorescence techniques. J. Phycol. 2007, 43, 1108-1119. [CrossRef]

48. Weigelhofer, G.; Pedro, J.; Pitzl, B.; Bondar-kunze, E.; Keeffe, J.O. Decoupled water-sediment interactions restrict the phosphorus buffer mechanism in agricultural streams. Sci. Total Environ. 2018, 628-629, 44-52. [CrossRef] [PubMed]

49. Pucher, M.; Wünsch, U.; Weigelhofer, G.; Murphy, K.; Hein, T.; Graeber, D. StaRdom: Versatile software for analyzing spectroscopic data of dissolved organic matter in R. Water 2019, 11, 2366. [CrossRef]

50. Murphy, K.R.; Stedmon, C.A.; Graeber, D.; Bro, R. Fluorescence spectroscopy and multi-way techniques. PARAFAC. Anal. Methods 2013, 5, 6557-6566. [CrossRef]

51. Riu, J.; Bro, R. Jack-knife technique for outlier detection and estimation of standard errors in PARAFAC models. Chemom. Intell. Lab. Syst. 2003, 65, 35-49. [CrossRef]

52. Murphy, K.R.; Stedmon, C.A.; Wenig, P.; Bro, R. OpenFluor-An online spectral library of auto-fluorescence by organic compounds in the environment. Anal. Methods 2014, 6, 658-661. [CrossRef]

53. Stedmon, C.A.; Markager, S. Resolving the variability in dissolved organic matter fluorescence in a temperate estuary and its catchment using PARAFAC analysis. Limnol. Ocean. 2005, 50, 686-697. [CrossRef]

54. Yamashita, Y.; Kloeppel, B.D.; Knoepp, J.; Zausen, G.L.; Jaffé, R. Effects of Watershed History on Dissolved Organic Matter Characteristics in Headwater Streams. Ecosystems 2011, 14, 1110-1122. [CrossRef]

55. Ejarque, E.; Khan, S.; Steniczka, G.; Schelker, J.; Kainz, M.J.; Battin, T.J. Climate-induced hydrological variation controls the transformation of dissolved organic matter in a subalpine lake. Limnol. Oceanogr. 2018, 63, 1355-1371. [CrossRef]

56. Gabor, R.S.; Baker, A.; McKnight, D.M.; Miller, M.P. Fluorescence Indices and Their Interpretation. In Aquatic Organic Matter Fluorescence; Coble, P.G., Lead, J., Baker, A., Reynolds, D.M., Spencer, R.G.M., Eds.; Cambridge Universiy Press: New York, NY, USA, 2014; pp. 303-338. ISBN 978-0-521-76461-2.

57. Helms, J.R.J.R.; Stubbins, A.; Ritchie, J.D.; Minor, E.C.E.C.; Kieber, D.J.D.J.; Mopper, K.; Stubbings, A.; Ritchie, J.D.; Minor, E.C.E.C.; Kieber, D.J.; et al. Absorption spectral slopes and slope ratios as indicators of molecular weight, source, and photobleaching of chromophoric dissolved organic matter. Limnol. Oceanogr. 2008, 53, 955-969. [CrossRef]

58. Weishaar, J.L.; Aiken, G.R.; Bergamaschi, B.A.; Fram, M.S.; Fujii, R.; Mopper, K. Evaluation of specific ultraviolet absorbance as an indicator of the chemical composition and reactivity of dissolved organic carbon. Environ. Sci. Technol. 2003, 37, 4702-4708. [CrossRef]

59. Lennon, J.T.; Pfaff, L.E. Source and supply of terrestrial carbon affects aquatic microbial metabolism. Aquat. Microb. Ecol. 2005, 39, 107-119. [CrossRef]

60. O'Brien, J.M.; Dodds, W.K. Saturation of $\mathrm{NO}_{3}{ }^{-}$uptake in prairie streams as a function of acute and chronic N exposure. J. N. Am. Benthol. Soc. 2010, 29, 627-635. [CrossRef]

61. Trentman, M.T.; Dodds, W.K.; Fencl, J.S.; Gerber, K.; Guarneri, J.; Hitchman, S.M.; Peterson, Z.; Rüegg, J. Quantifying ambient nitrogen uptake and functional relationships of uptake versus concentration in streams: A comparison of stable isotope, pulse, and plateau approaches. Biogeochemistry 2015, 125, 65-79. [CrossRef]

62. Knapik, H.G.; Fernandes, C.V.S.; de Azevedo, J.C.R.; dos Santos, M.M.; Dall'Agnol, P.; Fontane, D.G. Biodegradability of anthropogenic organic matter in polluted rivers using fluorescence, UV, and BDOC measurements. Environ. Monit. Assess. 2015, 187, 1-15. [CrossRef]

63. Kamjunke, N.; Lechtenfeld, O.J.; Herzsprung, P. Quality of dissolved organic matter driven by autotrophic and heterotrophic microbial processes in a large river. Water 2020, 12, 1577. [CrossRef]

64. Kuehn, K.A.; Francoeur, S.N.; Findlay, R.H.; Neely, R.K. Priming in the microbial landscape: Periphytic algal stimulation of litter-associated microbial decomposers. Ecology 2014, 95, 749-762. [CrossRef] [PubMed]

65. Howard-Parker, B.; White, B.; Halvorson, H.M.; Evans-White, M.A. Light and dissolved nutrients mediate recalcitrant organic matter decomposition via microbial priming in experimental streams. Freshw. Biol. 2020, 1-11. [CrossRef]

66. Danger, M.; Cornut, J.; Chauvet, E.; Chavez, P.; Elger, A.; Danger, M.; Cornut, J.; Chauvet, E.; Chavez, P.; Elger, A. Benthic algae stimulate leaf litter decomposition in detritus-based headwater streams: A case of aquatic priming effect? Ecology 2013, 94, 1604-1613. [CrossRef] [PubMed] 
67. Guenet, B.; Danger, M.; Abbadie, L.; Lacroix, G. Priming effect: Bridging the gap between terrestrial and aquatic ecology. Ecology 2010, 91, 2850-2861. [CrossRef]

68. Wyatt, K.H.; Rober, A.R. Warming enhances the stimulatory effect of algal exudates on dissolved organic carbon decomposition. Freshw. Biol. 2019, 1-10. [CrossRef]

69. Catalán, N.; Kellerman, A.M.; Peter, H.; Carmona, F.; Tranvik, L.J. Absence of a priming effect on dissolved organic carbon degradation in lake water. Limnol. Oceanogr. 2015, 60, 159-168. [CrossRef]

70. Halvorson, H.M.; Barry, J.R.; Lodato, M.B.; Findlay, R.H.; Francoeur, S.N.; Kuehn, K.A. Periphytic algae decouple fungal activity from leaf litter decomposition via negative priming. Funct. Ecol. 2019, 33, 188-201. [CrossRef]

71. Romaní, A.M.; Amalfitano, S.; Artigas, J.; Fazi, S.; Sabater, S.; Timoner, X.; Ylla, I.; Zoppini, A. Microbial biofilm structure and organic matter use in mediterranean streams. Hydrobiologia 2013, 719, 43-58. [CrossRef]

72. Mineau, M.M.; Wollheim, W.M.; Buffam, I.; Findlay, S.E.G.; Hall, R.O., Jr.; Hotchkiss, E.R.; Koenig, L.E.; McDowell, W.H.; Parr, T.B. Dissolved organic carbon uptake in streams: A review and assessment of reach-scale measurements. J. Geophys. Res. Biogeosci. 2016, 121, 2019-2029. [CrossRef]

Publisher's Note: MDPI stays neutral with regard to jurisdictional claims in published maps and institutional affiliations.

(C) 2020 by the authors. Licensee MDPI, Basel, Switzerland. This article is an open access article distributed under the terms and conditions of the Creative Commons Attribution (CC BY) license (http://creativecommons.org/licenses/by/4.0/). 